\title{
Optimization of pH in Ammonia, Heavy Metals, and Chlorophyll-a Removal by using Electric Arc Furnace Slag and Activated Carbon Cassava Peel
}

\author{
Nabilah Zayadi ${ }^{1}$, Shareen Hwong Shiaw Ling ${ }^{1}$, Norzila Othman ${ }^{1, *}$ and Rafidah Hamdan ${ }^{1}$ \\ ${ }^{1}$ Department of Water and Environmental Engineering, Faculty of Civil and Environmental \\ Engineering, University Tun Hussien Onn Malaysia
}

\begin{abstract}
The wastewater contain high concentrations of inorganic and organic pollutant and that could be toxic to aquatic life and may lead to toxic environment of the water bodies. The poolutants able to accumulate in living tissues, causing various illnesses. In this study, parameters that affected the removal of heavy metals, ammonia $\left(\mathrm{NH}_{4}-\mathrm{N}\right)$ and chlorophyll-a were investigated in a synthetic water of mixed metals, $\mathrm{NH}_{4}-\mathrm{N}$, and alga synthetic solution. The removal was strongly affected by $\mathrm{pH}$ by using activated carbon cassava peel (CPAC) and Electric Arc Furnace Slag (EAFS) as media For CPAC, optimum condition for removing heavy metals, $\mathrm{NH}_{4}-\mathrm{N}$ and chlorophyll-a can be achieved at $\mathrm{pH} 7.5$ where removal up to $95 \%$ for heavy metals, $49.2 \%$ for $\mathrm{NH}_{4}-\mathrm{N}$ and $56.8 \%$ for chlorophylla. While for EAFS, the optimum condition for removing heavy metals, $\mathrm{NH}_{4}-\mathrm{N}$ and chlorophyll-a can be achieved at $\mathrm{pH} 7.5$ where removal up to $93 \%$ for heavy metals, $77.7 \%$ for $\mathrm{NH}_{4}-\mathrm{N}$ and $80.7 \%$ for chlorophyll-a. In order to obtain the maximum removal of heavy metals, $\mathrm{NH}_{4}-\mathrm{N}$ and chlorophyll-a, two conditions obtaining CPAC and EAFS were considered. The optimum condition for removing heavy metals, $\mathrm{NH}_{4}-\mathrm{N}$ and chlorophyll-a by $1 / 3$ CPAC $+2 / 3$ EAFS was $\mathrm{pH} 7.5$ as well where removal up to $95 \%$ for heavy metals, $86.2 \%$ for $\mathrm{NH}_{4}-\mathrm{N}$ and $90.9 \%$ for chlorophylla. By using 1/3 EAFS + 2/3 CPAC, the optimum removal of heavy metals, $\mathrm{NH}_{4}-\mathrm{N}$ and chlorophyll-a was at $\mathrm{pH} 7.5$ where removal up to $96 \%$ for heavy metals, $80.7 \%$ for $\mathrm{NH}_{4}-\mathrm{N}$ and $86.4 \%$ for chlorophyll-a. This study highlighted that EAFS and CPAC peel are promising method in removing $\mathrm{Zn}, \mathrm{Al}, \mathrm{Fe}$ ions, $\mathrm{NH}_{4}-\mathrm{N}$ and chlorophyll-a from aqueous solution.
\end{abstract}

\section{Introduction}

One of the major concerns of this century is the preservation of environmental quality. Water contamination and shortage of clean water is one of the most urgent problems for human activities. The water quality degenerated caused by enrichment of nutrients and heavy metals which help the growth of algae species and lastly cause eutrophication which

* Corresponding author: norzila@uthm.edu.my 
defined as the excessive enrichment of waters by nutrients are widespread in lakes and reservoirs throughout the world [1]. In order to eliminate targeted heavy metals, ammonia and chlorophyll-a, biosorbent with most favorable and hold high composition of elements and functional groups were selected [2-4]. Maximum biosorption particularly occurs in weak acidic $\mathrm{pH}$ because of the involvement of carboxyl group and other acidic functional groups. These groups were responsible for binding metal cations through various mechanisms [5]. Moreover, the presence of $\mathrm{Si}, \mathrm{Ca}, \mathrm{Mg}, \mathrm{Fe}$, rich in functional groups and surface porosity of media were significant factors which attribute to facilitate heavy metals and nutrient removal [6]. Study by Nabilah et al., [6] supports the potential use of cassava peel and steel slag through characterization of medias by XRF, FTIR, FESEMEDX, XRD and TG analysis.

EAFS was used to remove phosphate and ammonia nitrogen from wastewater. EAFS has benefits such as loose structure, large pores, stable chemical composition, and it contains the free $\mathrm{CaO}, \mathrm{MgO}$ and $\mathrm{Fe}$ and therefore effect filtration, adsorption, and precipitation on the pollutants (ammonia, chlorophyll-a and heavy metals) in the water [7, 8]. CPAC is an eventual cheap biosorbent for metal ions sequestration. Therefore, this paper will evaluate the potential of EAFS and CPAC in removing ammonia, heavy metal and chlorophyll-a.

\section{Materials and Methods}

\subsection{Preparation of CPAC}

Cassava peel was gathered at Kilang Kerepek Ahmad Shah, Parit Raja Darat, Johor. Raw fruit peels were soaked together with distilled water for extra clean up for a minimum of 24 hours and dried in an oven overnight. Cassava peel was pre-treated with 5\% of nitric acid $\left(\mathrm{HNO}_{3}\right)$ for 6 hours to get rid of attached dust and soluble impurities from the surface. Next, it was oven-dried for 24 hours and continues to be for impregnation process. Prior to carbonization, the dried peel was impregnated using phosphoric acid 30\% v/v for 6 hours. The impregnated peel then oven-dried at $110^{\circ} \mathrm{C}$ and kept for carbonization process [9]. Impregnated peel using phosphoric acid $30 \%(\mathrm{v} / \mathrm{v})$ was used in the carbonization. This process was done in muffle furnace at temperature of $380^{\circ} \mathrm{C}$ with a heating rate of $5^{\circ} \mathrm{C} / \mathrm{min}$ at 5 min holding time. The soaking duration at final temperature was 30 minutes. As the starting material is non-woody originates, the temperature-ramp was conducted at the rate of $5^{\circ} \mathrm{C} / \mathrm{min}$ at 5 minutes holding time.

Finally, the activated samples were cooled to room temperature before it was taken out from the furnace [9]. The samples required to wash to reduce its $\mathrm{pH}$ and to eliminate ash from the surface of AC. The samples were washed batch wise at room temperature with hot water $70^{\circ} \mathrm{C}$ several times followed by cool distilled water until the filtrate reached approximately $\mathrm{pH}$ 6-7 [10]. After that, the washed samples were oven-dried at $85^{\circ} \mathrm{C}$ until constant weight [9]. CP-AC were then sieved to get particle size between $0.833 \mathrm{~mm}-2.36$ $\mathrm{mm}(8 / 20$ mesh size). Finally, the samples were kept in tight bottle for analysis.

\subsection{Preparation of EAFS}

Electric Arc Furnace Slag (EAFS) were collected at Antara Steel Mills, Pasir Gudang, Johor. EAFS were used to remove total nutrient in this study. XRF and SEM-EDX analysis were performed to analyze chemical compositions and elemental distributions, respectively. EAFS were washed with tap water two times and then followed by distilled water once. This process was done in order to remove any dirt or particulate that adheres to the media 
before being used for batch study. The washed media were oven dried at $105^{\circ} \mathrm{C}$ for 24 hours and sieved to obtain $10-20 \mathrm{~mm}$ of particle size [11].

\subsection{Experimental design in batch study for optimization of $\mathrm{pH}$}

All experiments were conducted using the batch technique by differing $\mathrm{pH}$ of mixed solution. Synthetic solution were prepared in mixed of $\mathrm{Fe}, \mathrm{Zn}, \mathrm{Al}$ ions, $\mathrm{NH}_{4}-\mathrm{N}$, and alga synthetic solution. The working condition of concentrated $\mathrm{NH}_{4}-\mathrm{N}$, heavy metals, and chlorophyll-a were selected based on results of Sembrong's water characterization. Each experiment was conducted in triplicate with three blank samples.

In this study, $100 \mathrm{ml}$ of initial concentration $\left(\mathrm{NH}_{4}-\mathrm{N}\right.$, heavy metals and alga) solution were prepared for each experiment. Biosorbent with aqueous solution was agitated at 125 rpm [12]. The samples were then centrifuged at $1400 \mathrm{rpm}$ within five minutes. At the end of each experiment, the biosorbent that had been filtered through $0.45 \mu \mathrm{m}$ filter paper will be kept in an airtight container. Finally, the supernatants were kept in airtight plastic bottles and analyzed to perform $\mathrm{NH}_{4}-\mathrm{N}$ and heavy metals while chlorophyll-a analysis were run immediately or stored in amber glass covered with aluminium foil. Sampling, sample preservation and laboratory analysis were based on Standard Methods for the Examination of Water and Wastewater [13]. Heavy metals were analyzed by Inductively Coupled Plasma-Mass Spectrometer (ICP-MS), $\mathrm{NH}_{4}-\mathrm{N}$ by distillation unit, and alga were measured as chlorophyll-a content .

\subsection{Effect of pH on heavy metal ions, ammonia, and chlorophyll-a removal}

In this study, $\mathrm{pH}\left(\mathrm{NH}_{4}-\mathrm{N}, \mathrm{Fe}, \mathrm{Zn}, \mathrm{Al}\right.$, and alga) solution were optimized by using batch study. Table 1 shows that working range of $\mathrm{pH}$ in synthetic solution.

Table 1. Working range of $\mathrm{pH}$ in synthetic solution.

\begin{tabular}{|c|c|c|c|c|c|c|c|c|}
\hline \multirow{3}{*}{ Biosorbent } & \multirow{3}{*}{$\begin{array}{c}\text { Parameter Test } \\
\text { pH }\end{array}$} & \multicolumn{7}{|c|}{ Constant Parameter } \\
\hline & & \multirow{2}{*}{$\begin{array}{c}\text { Time } \\
\text { (hr) }\end{array}$} & \multirow{2}{*}{$\begin{array}{l}\text { Dosage } \\
\text { (g) }\end{array}$} & \multicolumn{5}{|c|}{ Initial Concentration $(\mathrm{mg} / \mathrm{L})$} \\
\hline & & & & $\begin{array}{c}\mathrm{NH} \\
4\end{array}$ & $\mathbf{F e}$ & $\mathbf{Z n}$ & Al & $\begin{array}{c}\text { Algae } \\
\text { (cell } / \mathrm{ml})\end{array}$ \\
\hline CPAC & $\begin{array}{c}\text { 3.0, 3.5, 4.0, 4.5, } \\
5.0,5.5,6.0,6.5 \\
7.0,7.5,8.0,8.5 \\
\quad 9.0\end{array}$ & 2 & 5 & 1.5 & 0.115 & 0.010 & 0.025 & 1000 \\
\hline EAFS & $\begin{array}{c}3.0,3.5,4.0,4.5, \\
5.0,5.5,6.0,6.5, \\
7.0,7.5,8.0,8.5, \\
9.0\end{array}$ & 2 & 20 & 1.5 & 0.115 & 0.010 & 0.025 & 1000 \\
\hline $\begin{array}{ll}1 / 3 & \text { CPAC } \\
+2 / 3 & \text { EAFS }\end{array}$ & $\begin{array}{c}3.0,3.5,4.0,4.5, \\
5.0,5.5,6.0,6.5, \\
7.0,7.5,8.0,8.5, \\
9.0\end{array}$ & 2 & $\begin{array}{c}1.7 \text { CPAC } \\
13.3 \\
\text { EAFS }\end{array}$ & 1.5 & 0.115 & 0.010 & 0.025 & 1000 \\
\hline $\begin{array}{l}\text { 1/3 EAFS+ } \\
\text { 2/3 CPAC }\end{array}$ & $\begin{array}{c}3.0,3.5,4.0,4.5 \\
5.0,5.5,6.0,6.5 \\
7.0,7.5,8.0,8.5 \\
9.0\end{array}$ & 2 & $\begin{array}{l}\text { 6.7 EAFS } \\
\text { 3.3CPAC }\end{array}$ & 1.5 & 0.115 & 0.010 & 0.025 & 1000 \\
\hline
\end{tabular}




\subsection{Data analysis for biosorption efficiency}

The removal efficiency for $\mathrm{NH}_{4}-\mathrm{N}$, heavy metals, and chlorophyll-a is determined using Equation (1). Equation 1 has been widely used and reported in previous studies on biosorption field $[12,14,15]$.

$$
\text { Percent removal }=\frac{C_{0}-C_{f}}{C_{0}} \times 100 \%
$$

Where:

$$
\begin{aligned}
& \mathrm{C}_{0}=\text { Initial concentration }(\mu \mathrm{g} / \mathrm{L} @ \mathrm{mg} / \mathrm{L}) \\
& \mathrm{C}_{\mathrm{f}}=\text { Final concentrations }(\mu \mathrm{g} / \mathrm{L} @ \mathrm{mg} / \mathrm{L})
\end{aligned}
$$

\section{Result and Discussion}

\subsection{Effect of pH}

The $\mathrm{pH}$ is a key factor that should be considered in the removal in heavy metals, $\mathrm{NH}_{4}-\mathrm{N}$ and chlorophyll-a. The extent of removal of ions is strongly influenced by the $\mathrm{pH}$ of the solution. Figures below showing the relationship graph between $\mathrm{pH}$ and percentage removal of heavy metals, $\mathrm{NH}_{4}-\mathrm{N}$ and chlorophyll-a by CPAC, EAFS and combination of CPAC and EAFS.

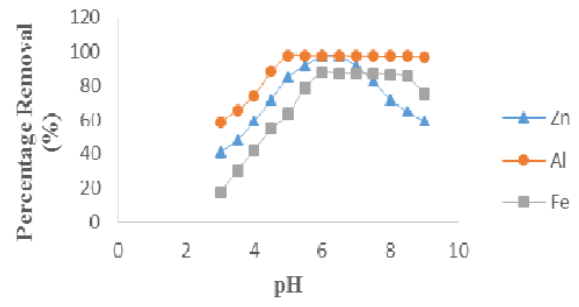

Fig. 1. Effect of $\mathrm{pH}$ on $\mathrm{Zn}, \mathrm{Al}$, and $\mathrm{Fe}$ ions removal by using CPAC

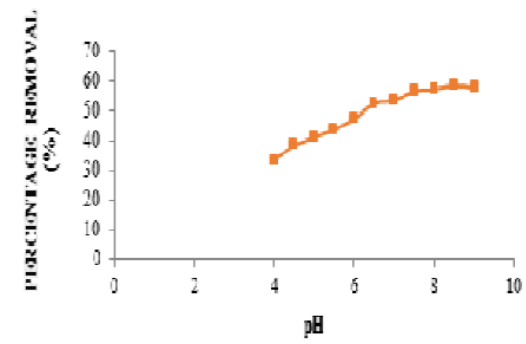

Fig. 3. Effect of $\mathrm{pH}$ on chlorophyll-a by using CPAC

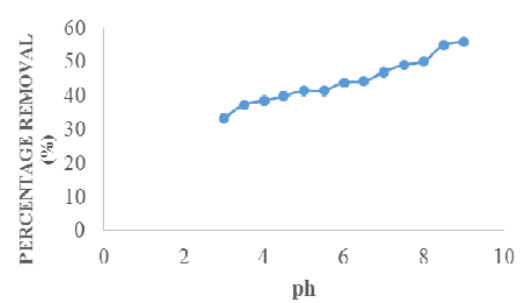

Fig. 2. Effect of $\mathrm{pH}$ on $\mathrm{NH}_{4}-\mathrm{N}$ removal by using CPAC

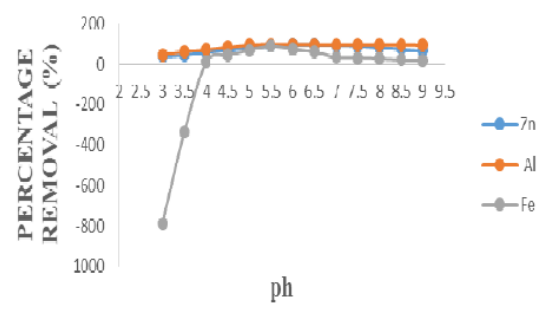

Fig. 4. Effect of $\mathrm{pH}$ on $\mathrm{Zn}, \mathrm{Al}$, and Fions removal by using EAFS

The effect of $\mathrm{pH}$ on removal of heavy metals, $\mathrm{NH}_{4}-\mathrm{N}$ and chlorophyll-a by using CPAC were shown in Fig. 1, 2, and 3. The optimum $\mathrm{pH}$ was 7.5 that resulted in removal up to $95 \%$ for heavy metals, $49.2 \%$ for $\mathrm{NH}_{4}-\mathrm{N}$ and $56.8 \%$ for chlorophyll-a. An increase of 
percentage removal above $\mathrm{pH} 7$ could be due to the electrostatic repulsion between the negatively charged species and the biosorbent surface. Hence, it can be concluded that an effective removal of heavy metals from aqueous solution can be accompanied by using CPAC and were supported through characterization of cassava peel by XRF, FTIR, FESEM-EDX and TG analysis [6].

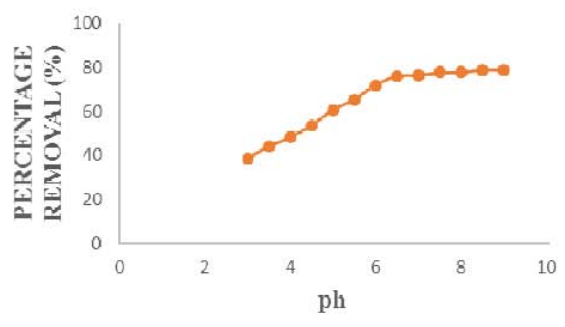

Fig. 5. Effect of $\mathrm{pH}$ on $\mathrm{NH}_{4}-\mathrm{N}$ by using EAFS

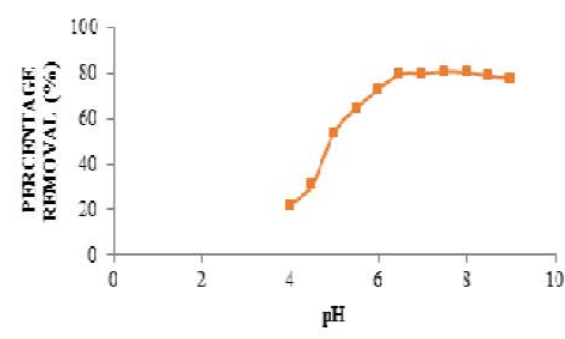

Fig. 6. Effect of $\mathrm{pH}$ on chlorophyll-a by using EAFS

Fig. 4, 5 and 6 show removal of metals, $\mathrm{NH}_{4}-\mathrm{N}$ and chlorophyll-a by using EAFS. The optimum $\mathrm{pH}$ was also 7.5 which resulted to removal up to $93 \%$ for heavy metals, $77.7 \%$ for $\mathrm{NH}_{4}-\mathrm{N}$ and $80.7 \%$ for chlorophyll-a. The results of the effect of $\mathrm{pH}$ on removal that the percentage removal by $\mathrm{NH}_{4}-\mathrm{N}$ is strongly dependent on $\mathrm{pH}$. The effect of $\mathrm{pH}$ on removal of heavy metals, $\mathrm{NH}_{4}-\mathrm{N}$ and chlorophyll-a by using $1 / 3$ CPAC $+2 / 3$ EAFS and 1/3 EAFS + 2/3 CPAC were shown in Fig. 7, 8, 9 and Fig. 10, 11, 12, respectively.

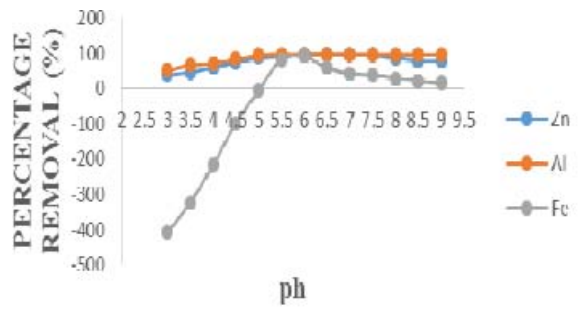

Fig. 7. Effect of $\mathrm{pH}$ on $\mathrm{Zn}, \mathrm{Al}$, and $\mathrm{Fe}$ ions by using $1 / 3$ CPAC $+2 / 3$ EAFS

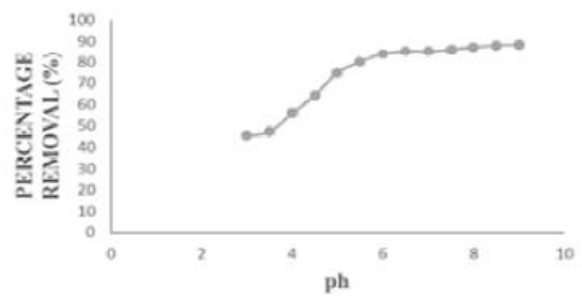

Fig. 8. Effect of $\mathrm{pH}$ on $\mathrm{NH}_{4}-\mathrm{N}$ by using $1 / 3$ $\mathrm{CPAC}+2 / 3$ EAFS 


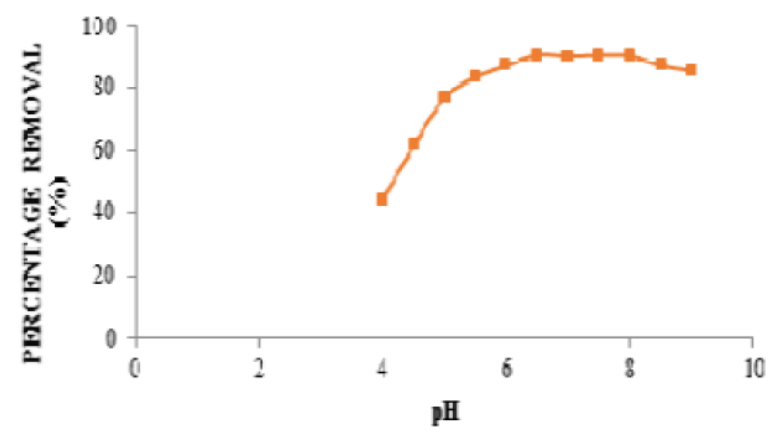

Fig. 9. Effect of $\mathrm{pH}$ on chlorophyll-a by using $1 / 3 \mathrm{CPAC}+2 / 3$ EAFS

The change of surface characteristics can affect removal efficiency to some extent. The surface characteristics of EAFS, such as the surface charge resulted from proton transfers at the surface. The increase of $\mathrm{OH}-$ in solution could affect the electrostatic properties of the slag. The presence of $-\mathrm{OH}$ on the surface of slag leads to the formation of a new charged layer, making the slag surface being a comparable lower affinity to ammonia.

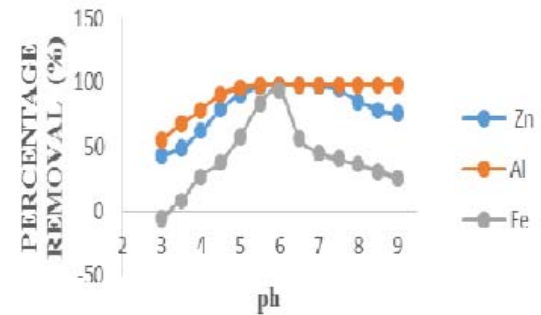

Fig. 10. Effect of ph on $\mathrm{Zn}, \mathrm{Al}$, and $\mathrm{Fe}$ ions by using $1 / 3$ EAFS $+2 / 3$ CPAC

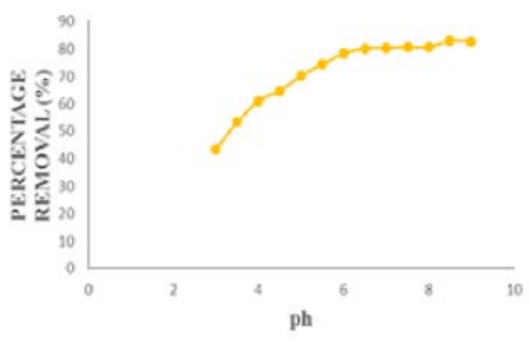

Fig. 11. Effect of $\mathrm{pH}$ on $\mathrm{NH}_{4}-\mathrm{N}$ by using $1 / 3$ $\mathrm{EAFS}+2 / 3$ CPAC

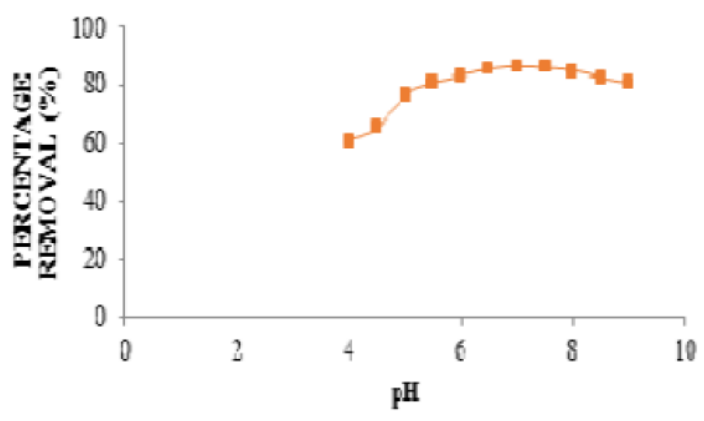

Fig. 12. Effect of $\mathrm{pH}$ on chlorophyll-a by using $1 / 3$ EAFS $+2 / 3$ CPAC

With an increase in $\mathrm{pH}, \mathrm{OH}-$ competes strongly with ammonia for active sites, which affects the removal efficiencies. This therefore implies that removal is favored by high $\mathrm{pH}$ values which was $\mathrm{pH} 7.5$. 


\section{Conclusions}

Based on the result obtained, it is proven that the $\mathrm{NH}_{4}-\mathrm{N}$, heavy metals and chlorophyll-a in the water could be removed by using CPAC and EAFS. Overall, all of the optimum $\mathrm{pH}$ are in $\mathrm{pH}$ 7.5. Condition using $1 / 3 \mathrm{CPAC}+2 / 3$ EAFS were slightly higher compared to other where removal up to $86.2 \%$ for $\mathrm{NH}_{4}-\mathrm{N}$ and $90.9 \%$ for chlorophyll-a. Meanwhile, condition using 1/3 EAFS + 2/3 CPAC achieved slightly higher in heavy metals removal which is $96 \%$. This study highlighted that EAFS and CPAC are promising method in removing Zn, $\mathrm{Al}, \mathrm{Fe}$ ions, $\mathrm{NH}_{4}-\mathrm{N}$ and chlorophyll-a from aqueous solution. The application of $\mathrm{CPAC}$ and EAFS were under range and they are not harmful to aquatic life.

This study was supported by the Fundamental Research Grant Scheme (FRGS Vot 1575) sponsored by Ministry of Higher Education (MOHE).

\section{References}

[1] V. H. Smith, Eutrophication of freshwater and coastal marine ecosystems a global problem, Environ Sci Pollut Res Int., 10(2), 126-39, (2003)

[2] Othman, N., Kueh. S.Y., Azizul Rahman, M-F-H and Hamdan, R, Watermelon rind: a potential adsorbent for zinc removal, Applied mechanics and material, 680, 146-149, (2014)

[3] N. Zayadi and N.Othman, Characterization and optimization of heavy metals biosorption by fish scale, Advanced Material Research, 795, 360-365, (2013)

[4] C. G. Rocha, D. A. M. Zaia, R. V. D. S. Alfaya and A. A. D. S. Alfaya, Use of rice straw as biosorbent for removal of $\mathrm{Cu}(\mathrm{II}), \mathrm{Zn}(\mathrm{II}), \mathrm{Cd}(\mathrm{II})$ and $\mathrm{Hg}(\mathrm{II})$ ions in industrial effluents, J. Hazard. Mater, 166(1), 383-388, (2009)

[5] N.Othman, A.Che-Azhar, and A. Suhaimi, Zinc removal using honeydew rind, Applied Mechanics and Material, 680, 150-153, (2014)

[6] N. Zayadi, N. Othman, R. Hamdan, A potential waste to be selected as media for metal and nutrient removal. In IOP Conference Series: Materials Science and Engineering 136(1), 012058, (2015)

[7] L.Huang, Vertical undercurrent steel slag applied to artificial wetlands to deal with high ammonia nitrogen sewage test research, China University and Mining Technology, (2009)

[8] H. Motz, J. Geiseler, Products of steel slags : an oppurtunity to save natural resources, Waste Manage, 21(3), 285-293, (2001)

[9] Z. M. Yunus, N. Othman, R. Hamdan, N. N. Ruslan, Characterization of phosphoric acid impregnated activated carbon produced from honey dew peel, Jurnal Teknologi. 76 (5), 15-19, (2015)

[10]R. G. D. Alvaro, R. Z. Elessandra, H. Elizabete, M. Fernande Aline, F. C. Cesar, Oxidation of fermented cassava starch using hydrogen peroxide, Carbohydr. Polym. 86(1), 185-191, (2011)

[11]W-A. Wan-Mohamed, R. Hamdan, N. Othman, Study of the pH effects on the phosphorus removal mechanism in lab-scale electric arc furnace slag and limestone filters in synthetic wastewater. Applied Mechanics and Mater., 752-753, 277-282, (2015) 
[12]K. Srividya and K. Mohanty, Biosorption of hexavalent chromium from aqueous solution by catla catla scales: Equilibrium and kinetics studies, Chem. Eng. J., 155, 666-673, (2009)

[13]APHA., AWWA., WEF, Standard Methods for the Examination of Water and Wastewater. 22nd ed. Washington, DC: American Public Health Association, (2012)

[14] V. K. Jha, Y. Kameshima, A. Nakajima, K. Okada, Utilization of steel-making slag for the uptake of ammonium and phosphate ions from aqueous solution, J. Hazard. Mater. 156(1-3), 156-162, (2008)

[15]M. H. Khamidun, M.A. Fullazaky, M.F.M. Din and A.R.M. Yusoff. Resistance of mass transfer, kinetic and isotherm study of ammonium removal by using a hybrid plug flow column reactor. Environment Energy and Sustainable Development-Sung, Koa \& Chen, 555-559, (2014). 